\title{
Metaphorical Perceptions of Academicians and Engineers on the Conceptions of Game and Exercise: The Case of Boston, Massachusetts
}

\author{
Hacer Ozge Baydar Arican (Corresponding author) \\ Sport Sciences Faculty, Gazi University, 06500, Ankara, Turkey \\ Tel: 90-(533)-398-8330Ｅ-mail: ozgebaydar@gazi.edu.tr
}

Received: November 20, 2021

Accepted: December 15, 2021

Published: December 31, 2021

doi:10.5296/jei.v7i2.19218

URL: https://doi.org/10.5296/jei.v7i2.19218

\begin{abstract}
Games and exercises, which have an important place in the life of the individual in every developmental period of humans as a social being contribute to the communication and interaction of the individual with the environment, to the development of social cognitive skills such as problem-solving, analytical thinking, creative thinking, and reasoning as well as positively affecting the physical and mental development. Individuals, who try to survive in a mentally and physically challenging and demanding work pace or by being inactive for a long time in front of a computer screen, spend their energy through games, exercises, and physical activities, and can be discharged by relaxing. In this respect, it is possible to evaluate the entire games, exercises, and physical activities as a driving force to gather energy again after a tiring work tempo or as a source of motivation to move away from mental and physical fatigue. It is considered that performing activities such as exercises and playing games by individuals, considering them as a way of life and evaluating the factors, which keep individuals away from these activities, can be possible by explaining individual perceptions on these issues. In the light of these data, the meanings and values associated with the concepts of games and exercises by academics and engineers who live in different cultural structures, who cannot allocate adequate time for games and exercises in a compulsory work tempo, or who can acquire internal and external motivation via games and exercises as well as exercise frequency and playing times. The present study was conducted to examine the perceptions of academics and engineers on the concepts of game and exercise via metaphor analysis in June 2019 with the participation of scientists, academicians, and engineers who participated in the 2019 International Microwave Symposium (IMS) at the Boston Convention and Exhibition Center in Boston, MA, USA, which was held with the
\end{abstract}


participation of many scientists, academicians, and engineers from all over the world as a total of 135 participants, 56 women and 79 men, who agreed to participate in the study voluntarily, made up the study group. The metaphor analysis form that was prepared by the researcher was used in obtaining the data to reveal the perceptions of the participants about the concepts of game and exercise. The participants were asked to complete the statements with the statements of "Game is like ... because ..." and "Exercise is like ... because ..." in addition to their age, gender, nationality, residence, occupation, perceived income status, and educational status. After the data were analyzed, various metaphors for the concepts of game and exercise were detected. Also, different game playing times and exercise frequencies emerged as a result of the self-evaluation of each participant.

Keywords: Game, Exercise, Academician, Engineer, Metaphor, Perception

\section{Introduction}

There has been an important increase in mechanization after the advancement of technology in the modern age, which caused the individual to make less physical effort when working and lead an inactive lifestyle. Physical activities and exercises such as hunting, imitating animal movements, dancing, walking, and running during the day were evaluated and applied with different understandings in different social structures, especially in the last periods of the 18th century since the existence of humanity, in parallel with the development of technology and the increase in the use of machines and mass production, and physical activity gained serious importance after the negative effects on human health (Paffenbarger, Blair, \& Lee, 2001). As a life, being active develops people physically and spiritually, also contributing to their social cohesion and well-being. Exercise and physical activity are not limited to sports and planned and recreational activities. Individuals can do exercises and physical activities almost anywhere in their lives and working environments such as education and healthcare institutions. There is a level of physical activity that is suitable for all ages, and it is acknowledged now that individuals of all ages benefit from these activities (Edwards \& Tsouros, 2006).

Game has been in human life since the existence of human beings. Playing games is among the most basic human characteristics. Although game is expressed as a system defined by several rules, in which the players enter into an artificial conflict resulting in a measurable winning, and game is a leisure activity and entertainment for adults (Huizinga, 1995; Salen \& Zimmerman, 2004).

Game is a universal phenomenon existing in some way from every human society to the nature of animals, and the existence of game dates back to prehistoric times. However, cultural differences appear in the types of games and in the time allocated to entertaining activities. When the ancient times were considered in the cultural context in the world, it is already known that the hunter and tribal communities e.g., Australian aborigines, Eskimos, or San people of South Africa spend more time for entertainment than any other community. Deserts and cold regions where these communities live are adequate for sustaining an average of four hours of work an adult despite the difficult conditions, and children do not need to contribute to meeting any workloads. Children are free to play most of their time, and even 
adults spend some time in a number of non-productive activities including games.

The thing that differs among cultures is not only the time allocated to games, but also the known and permitted game types. It is possible to classify the game as follows by simplifying it without creating a complex structure:

(1) Games of physical skill (races, darts) in which the results are determined by the motor activity of the player;

(2) Games of chance (dice, roulette, bingo, playing cards) in which the results are determined by guessing or randomly;

(3) Strategy games (chess, checkers) in which the results are determined by rational choices;

(4) Symbolic games, usually with no winner or loser.

Games of physical skill exist in almost every society. Sometimes such games are considered as a useful manipulation of aggression, sometimes as a harmless but implicit way of preparing for war. Games of chance are less diverse in hunter- and tribal societies, or in societies with economic or social uncertainty, and may even be banned or simply attributed to magic ceremonies. However, there are more strategy games in these societies, namely, game types reflect the dominant lifestyle or structure of a society, contributing to children and adults in acquiring and maintaining the attitudes and values required by the dominant cultural norms. Children spend time with creative social drama and symbolic activities reflecting a wide variety of roles they have the chance to play as adults in industrialized Western societies, where it is important to achieve success with symbolic elements with purely imaginary heroes who are inspired by comics and television. If being healthy is not only the absence of a disease but also the use of developmental latent power of an individual in physical, social, emotional, moral, and cognitive fields, namely, good mental health, encouraging games is a part of preventive medicine (Rasen \& Öngen, 1993).

The concept of game was expanded after the development of technology, and the average age of individuals who play games increased. It is also important to determine what the game image in the minds of individuals is and whether it differentiates according to their developmental levels after the differentiation of the perception of the game concept. Games played on the screen have been introduced after the introduction of arcades into our lives since the 1970s. Games that were played with handheld devices also took place in our lives along with Atari games. Video games started to be played with game consoles installed on televisions after the development of computers (Creswell, 2013; Paffenbarger, Blair, \& Lee, 2001). As technology continues to develop, digital games started to be played frequently by adults with devices that had screens such as smartphones and tablets. Digital games, video games, and computer games are defined as games that are played with screens. Digital games give the ability to perform tasks requiring divided attention faster and more accurately, make simulations easier to understand, provide the ability to read and interpret 3D data, namely, visual-spatial elements, support the development of social and communication skills because they offer an active learning setting and support the acquisition of skills, namely the 
development of educational and cognitive skills. Among the next-generation computer games, commercial games contain simulations of real-world situations in which complex artificial intelligence allows players to make their own choices and see the effects of their decisions. In games, this technological development ensures that high-quality educational games are strengthened and entertaining at sufficient levels (Gökkaya, 2014).

Individuals who try to live in a challenging and demanding pace mentally and physically in our present day cannot allocate enough time for games, exercise, and physical activity. It is very important for the individual to be able to meet many needs such as rest, relaxation, discharge, mental, and physical regeneration outside of work as a social being. Meeting these needs will not only increase the efficiency at work, but will also prepare the ground for the strengthening social and human relations of the individual. Meeting the need for movement will also enable the individual to be healthy not only in physical terms but also in mental terms, and will enable many negative emotions such as stress, anxiety, and anxiety to be taken under control. All exercises and physical activities, which are considered very important for the individual in every developmental period, will keep individuals away from many mental diseases, especially chronic diseases. In this respect, it is possible to consider game, exercise, and physical activity as a driving force to gather energy again by moving away from the tiring and challenging work tempo, or as a motivation source by moving away from mental and physical fatigue sources.

The individual may have to work for long hours standing up or sitting in front of a computer screen in business life, which causes individuals who work in some occupational groups to experience many health problems such as posture disorders and loss of function especially for academics and individuals who perform the engineering profession. Although many muscle groups shorten after standing in the same position, and many muscle groups become tense. Staying in the same position for a long time impairs the functionality of the joints and muscles by preventing them from moving correctly. Continuous sitting can also cause the upper part of the spine to bend forward causing many health problems such as kyphosis. Experts who explore maintaining a healthy life agree that if there is inactivity, exercise is a must. It is considered that performing activities such as exercises and games, considering these as a way of life, and evaluating the factors keeping individuals away from these activities can be possible by explaining individual perceptions on these issues by individuals. In the light of these data, scientific academicians and engineers, who cannot allocate adequate time for games and exercises in an intense and challenging work setting, or who can gain internal and external motivation with games and exercises, and who live in different cultural settings, have a different understanding regarding the game and exercise concepts, as well as exercise frequency and duration of game and in this regard, the meanings and values created curiosity. Based on this viewpoint, the study was conducted to examine the perceptions of academicians and engineers on the concepts of game and exercise through metaphor analysis.

\section{Method}

Information on the study model, study group, data collection, and data analysis is given in this section. 


\section{MIMacrothink}

\subsection{Study Model}

The Phenomenology Design, which is one of the qualitative study methods, was used to obtain detailed data and understand and express the personal perceptions, experiences, and perspectives of participants of the study, which was conducted to examine the perceptions of individuals on the concepts of game and physical activity (Büyüköztürk, Çakmak, Akgün, Karadeniz \& Demirel, 2017). The Phenomenology Design is a qualitative research approach examining and interpreting the current experiences and perspectives of an individual on phenomena or concepts (Creswell, 2013).

\subsection{Study Group}

The study group was formed with the Purposeful Sampling Method. A total of 135 scientist academician and engineer participants, 56 of whom were female and 79 male, who participated in the International Microwave Symposium (IMS) that was held at the Boston Convention and Exhibition Center in Massachusetts, Boston, the USA on 02-07 June 2019, were included in the study. The Purposeful Sampling Method covers the identification, selection, and separation of the knowledgeable, competent, and experienced person or persons about the event or situation in question (Yağar \& Dökme, 2018). The voluntary participation of the academicians and engineers who constituted the study group selected with the Purposeful Sampling Method, was considered as the study criteria.

Table 1. The demographic distribution of the participants

\begin{tabular}{|l|l|l|l|}
\hline & Groups & $\mathrm{n}$ & $\%$ \\
\hline \multirow{5}{*}{ Age } & $21-29$ & 46 & 34.0 \\
& $30-39$ & 64 & 46.8 \\
& $\geq 40$ & 25 & 19.1 \\
& Total & 135 & 100.0 \\
\hline \multirow{5}{*}{ Gender } & Male & 79 & 57.4 \\
& Female & 56 & 42.6 \\
& Total & 135 & 100.0 \\
\hline \multirow{5}{*}{ Nationality } & Chinese & 27 & 20.0 \\
& Boston & 18 & 13.3 \\
& USA & 13 & 9.6 \\
& Korean & 11 & 8.1 \\
& Turkish & 9 & 6.7 \\
& Taiwanese & 9 & 6.7 \\
& South Korean & 8 & 5.9 \\
& English & 6 & 4.4 \\
& Portuguese & 6 & 4.4 \\
\hline
\end{tabular}




\begin{tabular}{|c|c|c|c|}
\hline & $\begin{array}{l}\text { French } \\
\text { Iranian } \\
\text { Italian } \\
\text { German } \\
\text { Austrian } \\
\text { Bosnian } \\
\text { Danish } \\
\text { Lithuanian } \\
\text { New Mexico } \\
\text { Polish } \\
\text { Slovenia } \\
\text { Lebanese } \\
\text { Ukrainian } \\
\text { Total }\end{array}$ & $\begin{array}{l}3 \\
3 \\
3 \\
3 \\
2 \\
2 \\
2 \\
2 \\
2 \\
2 \\
2 \\
1 \\
1 \\
135\end{array}$ & $\begin{array}{l}2.2 \\
2.2 \\
2.2 \\
2.2 \\
1.5 \\
1.5 \\
1.5 \\
1.5 \\
1.5 \\
1.5 \\
1.5 \\
0.7 \\
0.7 \\
100.0\end{array}$ \\
\hline Country/City living & $\begin{array}{l}\text { Boston } \\
\text { USA } \\
\text { California } \\
\text { Atlanta, GA } \\
\text { Taiwan } \\
\text { Miami, FL } \\
\text { Davis, CA } \\
\text { Seoul } \\
\text { Ankara } \\
\text { Mexico } \\
\text { Portugal } \\
\text { Istanbul } \\
\text { Merrimack, NH } \\
\text { Sweden } \\
\text { Tianjin } \\
\text { Florida } \\
\text { Philadelphia } \\
\text { Los Angeles } \\
\text { Berlin } \\
\text { Mesa, AZ } \\
\text { Stuttgart } \\
\text { Vinnitsa } \\
\text { Luxemburg }\end{array}$ & $\begin{array}{l}25 \\
23 \\
9 \\
9 \\
8 \\
7 \\
6 \\
5 \\
4 \\
4 \\
4 \\
3 \\
3 \\
3 \\
3 \\
3 \\
3 \\
3 \\
2 \\
2 \\
1 \\
1 \\
1\end{array}$ & $\begin{array}{l}18.5 \\
17.0 \\
6.7 \\
6.7 \\
5.9 \\
5.2 \\
4.4 \\
3.7 \\
3.0 \\
3.0 \\
3.0 \\
2.2 \\
2.2 \\
2.2 \\
2.2 \\
2.2 \\
2.2 \\
2.2 \\
1.5 \\
1.5 \\
0.7 \\
0.7 \\
0.7\end{array}$ \\
\hline
\end{tabular}




\begin{tabular}{|l|l|l|l|}
\hline & Jordan & 1 & 0.7 \\
& Lyon & 1 & 0.7 \\
& Bratislava & 1 & 0.7 \\
& Total & 135 & 100.0 \\
\hline \multirow{5}{*}{ Profession } & Academician & 48 & 36.6 \\
& Engineer & 87 & 63.4 \\
& Total & 135 & 100.0 \\
\hline \multirow{5}{*}{ Perceived income level } & Low & 43 & 33.9 \\
& Medium & 65 & 46.7 \\
& High & 27 & 19.4 \\
& Total & 135 & 100.0 \\
\hline \multirow{5}{*}{ The status of doing exercises } & BSc & 73 & 49.1 \\
& MSc & 41 & 32.2 \\
& PhD & 21 & 18.7 \\
& Total & 135 & 100.0 \\
\hline & Never & 38 & 26.7 \\
& Total than 3 times in a & 74 & 55.5 \\
& Total & 135 & 17.8 \\
\hline
\end{tabular}

When Table 1 is examined, it is seen that $79(57.4 \%)$ of the participants were male, and 56 (42.6\%) were female. When the distribution of the participants was evaluated according to age range, there were $46(34.0 \%)$ individuals in the 21-29 age group, 64 (46.8\%) in the 30-39 age group, and 25 (19.1\%) individuals who were aged 40 and over. When the nationalities and residences of the participants were examined, it was found that there are many countries in the world including Turkey. A total of 48 of the participants were academicians, and 87 were engineers. When the perceived income levels of each participant were examined, 43 individuals perceived their income as low, 65 individuals perceived their income as moderate, and 27 individuals perceived their income as high. When the educational status of the participants was evaluated, there were 73 undergraduates, 41 graduates, and 21 individuals who had doctorate degrees. In terms of doing exercises, it was observed that there were 38 individuals who did not exercise at all, 74 individuals did 1-3 exercises a week, and 23 individuals exercised more than 3 times a week.

\subsection{Obtaining the Data}

The data of the study were obtained with a metaphor form that showed personal opinions and that consisted of semi-structured questions that were prepared by the researcher. The participants were asked to create a metaphor about the concepts of game and exercise, and to 
analyze what kind of connotation this metaphor had in this form. With the understanding that the only use of the concept chosen as the metaphor might be insufficient in the explanation, it was stated that the question of "why" should be asked after describing the metaphor (Y1ldirım \& Şimşek, 2013). In this context, the participants were asked to complete the statements "Game is like ... because ...", and "Exercise is like ... because ..." in addition to their age, gender, nationality, place of residence, occupation, perceived income status, and educational status. The data were obtained from the participants with the permission of the Boston Convention and Exhibition Center, where the researcher also participated as a guest researcher, and the study was conducted by declaring its compliance with ethical principles. Each individual who participated in the study voluntarily was informed about the relevant consent and ethical framework. The data forms that were prepared by the researcher were applied to the participants during coffee hours and between sessions after the presentations of the participants at the International Microwave Symposium (IMS). The time that was required to answer the application forms was approximately 10 minutes for each participant. The data was collected in the International Microwave Symposium by the researcher as a guest with a badge number of 508323 and the approvals of the all participants were obtained with utilizing "Informed Voluntary Consent Form". Furthermore, the study was carried out accordance with the "Helsinki Declaration".

\subsection{Analysis of Data}

The data that were obtained in the study were analyzed by using the Content Analysis Method, which is one of the qualitative research data analysis methods. The Content Analysis is a scientific method where it is possible to examine the verbally expressed facts and concepts in line with certain principles, rules, and with an objective viewpoint, and to classify according to similarities (Büyüköztürk et al., 2017). The metaphors that were developed by the participants in the study were analyzed in four stages: generation and elimination of the codes step, sample metaphor chart determination step, category creation step, and ensuring validity and reliability step. Forms with ambiguity and inconsistency were not included in the analyses when incompletely filled metaphor forms and opinions about metaphor were expressed. It was investigated whether the participants created the metaphors in an easy-to-understand and ambiguous way in the code generation and elimination step during which 9 metaphors were excluded from the study because of the inability to read the items written by the participants well enough and incomplete data. In the determining the sample metaphor chart step, the remaining data were examined again, and a highly representative sample metaphor chart was created for each metaphor after the excluded forms were removed from the study. Information on which participant created a metaphor expression was named as "P1" for "Participant 1"; and metaphors related to the concepts of game and exercise were categorized by the participants in terms of common qualities in the categorization step. When the last stage of ensuring validity and reliability was considered, two critical points were detected in establishing the validity and reliability of the study. The first was to reach categories from metaphors. The second was the power of metaphors in representing the conceptual category. Two field experts analyzed the data to reveal the representation power of the conceptual categories reached by the analysis of the data to ensure the reliability of the 
research, and the codes and the categories represented by the codes were compared. Reliability calculation of content analysis was made by using the formula [Agreement / (Agreement + Disagreement) $\times 100$ ] (Miles \& Huberman, 1994). A total of 30 metaphors were obtained in 4 categories related to the concept of game, and 67 metaphors were obtained in 8 categories related to the concept of exercise in the study. A total of 97 metaphors on both concepts were obtained, and 3 metaphors were not in agreement. According to Miles and Huberman (1994), studies in which the reliability rate was calculated to be $70 \%$ or more were considered reliable in qualitative research. When the reliability of this study was calculated, it was recorded as $92 \%$.

\section{Results}

The metaphors that the participants mentioned on the concept of game, the categories brought together by these metaphors, and the expressions in these categories were presented in tables in this section.

Table 2. The distribution of the metaphors created by the participants for the concept of "Game" according to categories

\begin{tabular}{|c|c|c|c|}
\hline Category & Metaphor & Metaphor frequency & Number of metaphors \\
\hline \multirow{10}{*}{ Entertainment } & Having fun (7) & \multirow{10}{*}{38} & \multirow{10}{*}{10} \\
\hline & Adrenalin (6) & & \\
\hline & Being happy (5) & & \\
\hline & Smile (4) & & \\
\hline & Spending time with friends (4) & & \\
\hline & Fun competition (4) & & \\
\hline & Spending time with family (3) & & \\
\hline & Communicating (3) & & \\
\hline & Party (1) & & \\
\hline & Reading (1) & & \\
\hline \multirow{6}{*}{ Relaxation and rest } & Rest the mind (4) & \multirow{6}{*}{16} & \multirow{6}{*}{6} \\
\hline & Feeling good (4) & & \\
\hline & Be motivated (4) & & \\
\hline & Re-energizing (2) & & \\
\hline & Source of motivation (1) & & \\
\hline & Dreaming (1) & & \\
\hline \multirow{2}{*}{ Struggle } & Rivalry (3) & \multirow{2}{*}{18} & \multirow{2}{*}{11} \\
\hline & Passion (3) & & \\
\hline
\end{tabular}




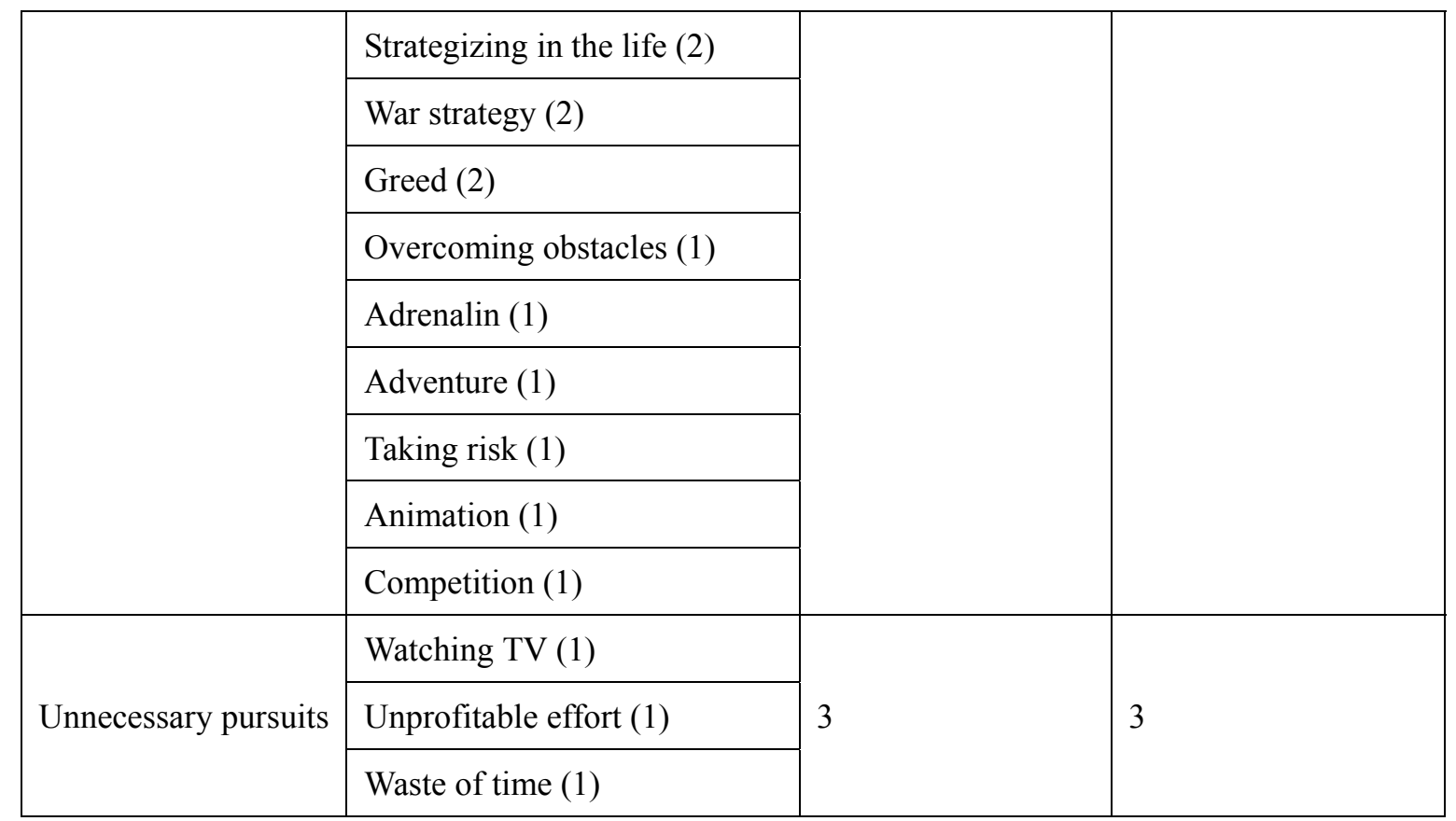

When Table 2 is examined, metaphors, frequency of metaphors, and numbers of metaphors were determined for each category. Four categories were created on the concept of game, entertainment, relaxation, rest, struggle, and unnecessary pursuits. The metaphors that represented each category are presented in the table for the frequency of the metaphor and the number of metaphors.

According to Table 2, the examples of metaphors created for the concept of "Game":

"Game like is a dreaming. Because I think of myself as a gladiator when I playin war games and I try to rescue all the slaves.

"Game is like having fun with family and friend. Because I feel happy like holding hands with my loved ones when I play. I smile when I enjoy the game."

"Game is like challenging and competition. Because it brings me enjoyment and is challenging."

"Game is like parenting activities with my children. Because When I play games with my children, I feel happy and even feel like a child."

"Game is like relaxation, fun, feeling my mind. Because I don't like to choose....

"Game is like an entertainment. Because it's relaxing and interesting."

"Game is like war strategies. Because in all the games you play, we have a purpose and to achieve this goal, different tactics must be applied. Whether to win the game or not depends on your tactics."

"Game is like an activity play with my friends, maybe table games, digital games such as football soccer, games inside the door. Because they are all relax me. Besides it's a good 
way to relax the pressure. More about that it also needs me to think more."

"Game is like a fun competition. Because you want to win and enjoy doing it such as digital games."

"Game is like spending time with friends and family. I like video games and chess. Because when I play chess and video games I get away from negative thoughts and chess is like life."

"Game is like playing computer games such as chess and car races. Because compelling is fun."

"Game is like adventure and adrenalin. Because heartbeats spend up and it makes me happy.

"Game is like source of motivation. Because when I play computer games 1 live in the moment and 1 am lost in time."

"Game is like sport competition and dreaming for real life. Because sports games like football also think about strategy planning in real life."

"Game is like my favorite book. Because the more I read it, the more I want to read it and get lost in it."

"Game is like watching TV. Because watching TV and playing games is an empty and unnecessary activity. People's time gets."

Table 3. The distribution of the metaphors created by the participants for the concept of "Exercise" according to categories

\begin{tabular}{|c|c|c|c|}
\hline Category & Metaphor & Metaphor frequency & Number of metaphors \\
\hline \multirow{8}{*}{ Addiction } & Love (4) & \multirow{8}{*}{15} & \multirow{8}{*}{8} \\
\hline & Habit (4) & & \\
\hline & Antidepressant (2) & & \\
\hline & Game (1) & & \\
\hline & Alcohol (1) & & \\
\hline & Harbour (1) & & \\
\hline & Drug (1) & & \\
\hline & Dependence (1) & & \\
\hline \multirow{4}{*}{ Need } & Need (8) & \multirow{4}{*}{20} & \multirow{4}{*}{8} \\
\hline & Nourish the soul (5) & & \\
\hline & Vitamin (2) & & \\
\hline & Nutrition (1) & & \\
\hline
\end{tabular}




\begin{tabular}{|c|c|c|c|}
\hline & Sleep (1) & & \\
\hline & Oxygen (1) & & \\
\hline & Energy drink (1) & & \\
\hline & Education (1) & & \\
\hline \multirow{10}{*}{ Entertainment } & Smiling (6) & \multirow{10}{*}{29} & \multirow{10}{*}{10} \\
\hline & Friend (5) & & \\
\hline & Feel happy (5) & & \\
\hline & Motivation (4) & & \\
\hline & Make friend (3) & & \\
\hline & Sport (2) & & \\
\hline & Reading (1) & & \\
\hline & Life (1) & & \\
\hline & New relations $(1)$ & & \\
\hline & The source of human (1) & & \\
\hline \multirow{9}{*}{ Utopia } & Dream (3) & \multirow{9}{*}{13} & \multirow{9}{*}{9} \\
\hline & Adventure (3) & & \\
\hline & New world (1) & & \\
\hline & Cinema (1) & & \\
\hline & Second life (1) & & \\
\hline & Another world (1) & & \\
\hline & Creating your own world (1) & & \\
\hline & Discovering a blissful island (1) & & \\
\hline & Discovery (1) & & \\
\hline \multirow{10}{*}{ Relaxation and rest } & Happiness (6) & \multirow{10}{*}{25} & \multirow{10}{*}{11} \\
\hline & Therapy (5) & & \\
\hline & Purification (3) & & \\
\hline & Meditation (3) & & \\
\hline & Freedom (2) & & \\
\hline & Place of relaxation (1) & & \\
\hline & Sun (1) & & \\
\hline & Yoga (1) & & \\
\hline & Withdrawal from work (1) & & \\
\hline & Physical activity (1) & & \\
\hline
\end{tabular}




\begin{tabular}{|c|c|c|c|}
\hline & Discharge (1) & & \\
\hline \multirow{6}{*}{ Competition } & Struggle (2) & \multirow{6}{*}{8} & \multirow{6}{*}{6} \\
\hline & Challenge (2) & & \\
\hline & Bravery (1) & & \\
\hline & Greed (1) & & \\
\hline & Survival strategy (1) & & \\
\hline & Overcome obstacles (1) & & \\
\hline \multirow{6}{*}{ Emotions } & Positive thinking (3) & \multirow{6}{*}{9} & \multirow{6}{*}{6} \\
\hline & Anger management (2) & & \\
\hline & Passion (1) & & \\
\hline & Sharing (1) & & \\
\hline & Resolution (1) & & \\
\hline & Self-confidence (1) & & \\
\hline \multirow{4}{*}{ Task } & Lifestyle (5) & \multirow{4}{*}{9} & \multirow{4}{*}{4} \\
\hline & Responsibility (2) & & \\
\hline & Principles (1) & & \\
\hline & Duty (1) & & \\
\hline \multirow{5}{*}{ Health } & Mental health (7) & \multirow{5}{*}{12} & \multirow{5}{*}{5} \\
\hline & Physical health (2) & & \\
\hline & Health (1) & & \\
\hline & Medicine (1) & & \\
\hline & Health promoting tool (1) & & \\
\hline
\end{tabular}

When Table 3 is examined, metaphors, frequency, and number of metaphors for each category were determined. Eight categories were created for the concept of exercise: addiction, need, entertainment, utopia, relaxation and rest, competition, emotions, task and health. The metaphors that represented each category are presented in the table with the frequency of the metaphor and the number of metaphors.

According to Table 3, examples of metaphors created for the concept of "Exercise":

"Exercise is like running. Because it clears my mind and relaxes me."

"Exercise is like education. Because as you work harder you get stronger."

"Exercise is like my refuge. Because when I'm exercising, I avoid negative thoughts and habits that harm me." 
"Exercise is like medicine. Because it makes me always healthy. It allows the body to release endorphins and build strength through endurance."

"Exercise is like a task. Because I have to go to gym and work hard on it."

"Exercise is like my lifestyle, swimming, running, and walking. Because when I do exercise, they bring me relaxing and let me think less, more about strengthen my body."

"Exercise is like a physical activity to make your body better and a stress release. Because it helps you get stronger and get out stresses and anger."

"Exercise is like drugs of abuse. Because game makes me crazy. Games interfere with my daily routine."

"Exercise is like my harbour. Because I can find my inner peace during exercise."

"Exercise is like oxygen. Because all people need oxygen to survive, and we can't live without oxygen."

"Exercise is like perseverance. Because you do it every day with great patience."

"Exercise is like being greedy. Because ambition is necessary to be successful in real life as well."

"Exercise is like theatre. Because for a few hours it makes different lives."

"Exercise is like self-confidence. Because a good body image makes me feel happy among other people especially those who are not fit and it's quite important to me to feel this way."

"Exercise is like creating new relationships. because you can try a new exercise method every day and this discovery can give you incredible excitement."

"Exercise is like a tool. Because improves health conditions and mood. I feel much more energetic and happier after exercise."

"The exercise is like a new world. Because it matters where you are and what you are doing while doing the exercise. There is none. The important thing is to imagine where he is, what he is doing. There is only dream."

"Exercise is like escaping from tiring work life. Because at that moment, even for a moment, the cruel world I forget."

"Exercise is like therapy. Because I get rid of all my troubles when I exercise."

Sample expressions of the participants on the frequency of exercise and the duration of playing games:

"I exercise at least 5 days a week. (Weightlifting and cardiovascular activity) for around 1-1.5 hour/day. I believe that this is higher activity than average. I usually spend time playing computer games on weekends." 
"I try to exercise myself in day-to-day activities as well as go to a gym once a week and maybe a few hours a week regarding my gaming time."

"I used to go to the gym 2 times in a week but in long periods I can't go because I don't have enough time, so I try to balance my calories with smaller portions. In addition, whenever I have the opportunity, I play a football match on the computer. I even have a very good team."

"Very important to make time for cardio and strength training are good. Fine something you enjoy doing. Varies based on travel 3-5 times a week. At home doing mostly cardio. When I'm not doing cardio exercises, I usually play chess or backgammon on the computer."

“Once a week is maximum. I don't really have much time for it, but I should. It should be critical part to individual life and people should spend time in maintaining their physical life. Just as I don't have enough time to exercise, I can't find enough time to play. But my find is that I can play car races on the computer or tablet at the first opportunity."

“Obligation for healthiness but my level of exercise is very low. I'm always busy so I need to exercise. I can't find the opportunity to play games in the same way."

"It is essential for creativity and work life balance. It contributes to not only physical health, but also mental health. I say doing 8 hour/week and 140 heart rates."

"Exercise is crucial to maintain good mentally health. I don't have enough time to exercise, but I walk to work, it's good for me."

"Exercise can be helpful to help you feel better, sleep well, feel productive and maintain heart health. On the other hand, especially playing strategy games can be a motivating factor for you when you are looking for solutions to the difficulties you encounter in your business life. Whenever I have a chance, I play games and exercise."

"I really like running and swimming, so I think the exercise is really relaxing myself. And more opportunity to communicating with friends. Mostly at weekend about 3 times and research or play games on the computer in my spare time."

When the views of the participants were evaluated on the frequency of exercise and the duration of playing games, it was found that the time devoted to exercises was more than that allocated to games for most other participants. However, participants performed activities such as cardio exercises, fitness, Pilates, swimming, cycling, walking, and jogging for an average of 1 hour in 3-5 days per week. The exercise intensities of the participants varied from mild to moderate and depended on the activity that was performed.

\section{Discussion}

When the relevant literature was reviewed, it was found that there are metaphorical perception studies on the concept of game in different occupational groups. Among these, in his study that examined pre-school teacher candidates' perceptions of the concept of game, 
Tok (2018) found that the categories that had the highest frequency were that game was relaxing, giving happiness, reflecting life, being a necessity, being a learning tool, imagining, teaching life, and reflecting the inner world. When the findings of Tok (2018) and the findings of this study were considered, the game perception shows parallelism as a means of entertainment, relaxation, and rest. In another study, Mclane (2003) asked preschool teachers to describe the game and its characteristics, and when the findings that were identified as a result of these definitions were evaluated, the game included entertaining, free, and enjoyable characteristics of a game. However, in the study in which Giren (2016) analyzed the perceptions of 75 preschool teachers on the game concept, it was reported that the majority of the teachers emphasized the educational and instructive roles of the game concept. Again, when the literature was reviewed, it was observed that categories on the roles of game were formed in the studies as a learning tool and educational role (Norgard, Toft-Nielsen, \& Whitton, 2017; Saracho \& Spodek, 1998; Sherwood \& Reifel, 2013).

When the relevant literature was reviewed, it was found that many national and international studies examined the metaphorical perceptions of teachers, students, and athletes of different branches regarding the concepts of exercise, physical activity, sports, and physical education (Elcombe, 2012; Güllü, 2021; Karagün, 2021; Miller, 1985; Segrave, 2000). In the present study, which was conducted to determine the metaphorical perceptions of academics and engineers on the game and exercise concepts, the categories and metaphors that emerged as a result of the content analysis method were in parallel with the data of the metaphorical perception studies that were conducted on the concepts of sports, physical activity, and physical education. In the light of these data, when the literature was reviewed, it was found that the most intense metaphors in the categories of the concept of sports were collected under the category of sports as an element of happiness and peace in the study that was conducted by Sevinç and Ergenç (2017) with students from different faculties of universities.

When the findings of this study and the relevant literature were evaluated, it can be revealed that the concepts of play and exercise in the world basically create the perception of entertainment, relaxation, and rest in the minds of individuals. In addition, when the developmental stages of individuals were examined, the concept of game evokes active games played mostly in open areas, especially in the early childhood and adolescence period. However, as individuals get older, the technological advances have led to the perception of digital games played with computers, tablets, and smart phones, especially in post-adolescence and adulthood. Moreover, increasing accessibility, especially through internet and online games, potentially focuses on each individual. However, both the digital games played with technological devices and the active games played in the open area, the meaning attributed to the game by the individuals and the effects of the game on the individuals are very close to each other. Furthermore, when the results of the study were evaluated, the study can be conducted in different occupational groups or within the framework of different socio-economic and cultural structures by using concepts independent of game and exercise to shed light on the studies that can be conducted in the future.

\section{Conclusion}


Metaphors, which are the only way to understand life, ourselves, and others, are mental tools including more powerful intellectual processes than explaining a concept merely with another concept in understanding and explaining phenomena, events, and concepts (Lakoff \& Johnson, 1980). When it was considered that the concepts of game and exercise may contain different mental images in different developmental periods, it was thought that many metaphors of different developmental periods may be required to explain game and exercise phenomena as a whole. When the results of this study, which was designed with this thought in mind, were evaluated, it was found that academicians and engineers created different metaphors for both concepts in this study, which was conducted to examine the perceptions of participants on the "game" and "exercise" concepts. When the categories of metaphors that were created on the game concept were examined, it was found that the most intense metaphors from 4 different categories, i.e., entertainment, relaxation, rest, struggle, and unnecessary effort, emerged in the categories of entertainment and relaxation and rest. It was also found that the game gives happiness, comfort, reflects life, is fun, and is consistent with Piaget's (1970) theory of construction, Vygotsy (1980) and Rubin, Fein, Vandenburg's (1983) explanations on games. Also, the theory of relaxation and regeneration of Lazarus, and the theory of exposing the body's natural excess of energy of Herbert Spencer, indicate that the game has a pleasing characteristic.

When the categories of metaphors that were created for the exercise concept were examined, it was found that the most intense metaphors of 8 different categories were need, entertainment, relaxation and rest, utopia, competition, addiction feelings, and task, occurred in the health, emotions, relaxation, and rest categories.

When the metaphorical perceptions of the participants on the concepts of game and exercise were evaluated, about the concept of "game", it can be argued that the perception of game was mostly in the form of fun, relaxation, and rest. Regarding the concept of "exercise", it can be argued that the perception of exercise was in the form of health, emotions, relaxation, and rest.

Another aspect of the study was when the views of the participants were evaluated regarding the frequency of exercise and the duration of playing games, it was found that the time devoted to exercise was more than that allocated to the game for the majority of the participants. Participants performed activities such as cardio exercises, fitness, pilates, swimming, cycling, walking and running for an average of 1 hour 3-5 days a week. The exercise intensities of the participants varied from mild to moderate depending on the activity that was performed. It was also found that the perception that emerged especially as a game consisted of computer games, digital games, games that were played with tablets or smart mobile phones. When the categories that were created for the game and exercise concepts were examined, it was understood that relaxation, rest, and entertainment were common categories for both concepts. To explain this, it can be argued that there is a perceptual similarity regarding the game and exercise concepts.

\section{References}

Büyüköztürk, Ş., Çakmak, E. K., Akgün, Ö. E., Karadeniz, Ş., \& Demirel, F. (2017). Bilimsel 
araştırma yöntemleri. Ankara: Pegem Atıf İndeksi. https://doi.org/10.14527/9789944919289

Creswell, J. W. (2013). Steps in conducting a scholarly mixed methods study. Retrieved from https://digitalcommons.unl.edu/cgi/viewcontent.cgi?article=1047\&context=dberspeakers

Edwards, P., \& Tsouros, A. D. (2006). Kentsel çevrede fiziksel aktivite ve aktif yaşamın desteklenmesi: Yerel Yönetimlerin Rolü. Dünya Sağl1k Örgütü.

Elcombe, T. L. (2012). Sport, aesthetic experience, and art as the ideal embodied metaphor. Journal of the Philosophy of Sport, 39(2), 201-217. https://doi.org/10.1080/00948705.2012. 725901

Giren, S. (2016). Okul öncesi öğretmenlerinin "okul öncesi dönem çocuğu için oyun" kavramına ilişkin metaforları. Eğitimde Kuram ve Uygulama, 12(1), 372-388.

Gökkaya, Z. (2014). Yetiskin eğitiminde yeni bir yaklaşım: Oyunlaştırma. Hasan Ali Yücel Egitim Fakültesi Dergisi, 11(1), 71-84.

Güllü, E. (2021). Metaphorical perceptions of physical education and sports: An evaluation from the perspective of preservice teachers. African Educational Research Journal, 9(1), 9-15. https://doi.org/10.30918/AERJ.9S1.21.005

Huizinga, J. (1995). Homo Ludens: Oyunun Toplumsal Isşlevi Üzerine Bir Deneme. İstanbul: Ayrıntı Yayınları.

Karagün, E. (2021). İlkokul ve ortaokulda farklı branşlarda çalışan öğretmenlerin "beden eğitimi" ve "spor" kavramlarına ilişkin metaforları. Eğitim ve Bilim, 46, 79-104. https://doi.org/10.15390/EB.2021.9230

Lakoff, G., \& Johnson, M. (1980). Conceptual metaphor in everyday language. The Journal of Philosophy, 77(8), 453-486. https://doi.org/10.2307/2025464

McLane, J. B. (2003). “Does Not.” Does Too.”: Thinking about Play in the Early Childhood Classroom. Chicago, IL: Erickson Institute.

Miller, D. F. (1985). Social policy: An exercise in metaphor. Knowledge, 7(2), 191-215. https://doi.org/10.1177/0164025985007002006

Miles, M. B., \& Huberman, A. M. (1994). Qualitative data analysis: An expanded sourcebook. Thousand Oaks, CA: Sage Publications.

Norgard, R. T., Toft-Nielsen, C., \& Whitton, N. (2017). Playful learning in higher education: Developing a signature pedagogy. International Journal of Play, 6(3), 272-282. https://doi.org/10.1080/21594937.2017.1382997

Paffenbarger Jr., R. S., Blair, S. N., \& Lee, I. M. (2001). A history of physical activity, cardiovascular health and longevity: The scientific contributions of Jeremy N Morris, DSc, DPH, FRCP. International Journal of Epidemiology, 30(5), 1184-1192. https://doi.org/ 10.1093/ije/30.5.1184

Piaget, J. (1970). Piaget's theory. In P. H. Mussen (Ed.), Carmichael's manual of child 
psychology. New York: John Wiley.

Rasen, P., \& Öngen, D. (1993). Oyunun değeri. Ĕgitim ve Bilim, 17(88), 60-64.

Rubin, K. H., Fein, G. G., \& Vandenberg, B. (1983). Play. In E. M. Hetherington (Ed.), Handbook of Child Psychology (Vol. 4). Socialization, Personality, and Social Development (4th ed.). New York: Wiley.

Salen, K., \& Zimmerman, E. (2004). Rules of play: Game design fundamentals. Massachusetts: MIT Press.

Saracho, O. N., \& Spodek, B. (1998). Multiple perspectives on play in early childhood education. New York: SUNY Press.

Segrave, J. O. (2000). The sports metaphor in American cultural discourse. Culture, Sport Society, 3(1), 48-60. https://doi.org/10.1080/14610980008721862

Sevinç, Ö. S., \& Ergenç, M. (2017). Düzce Üniversitesi’nin bazi fakültelerinde öğrenim görmekte olan lisans öğrencilerinin "spor” hakkindaki metaforlari. Düzce Üniversitesi Sosyal Bilimler Enstitüsü Dergisi, 7(2), 106-131.

Sherwood, S. A. S., \& Reifel, S. (2013). Valuable and unessential: The paradox of preservice teachers' beliefs about the role of play in learning. Journal of Research in Childhood Education, 27(3), 267-282. https://doi.org/10.1080/02568543.2013.795507

Tok, E. (2018). Okul öncesi öğretmen adaylarının oyuna ilişkin algıları: Metafor analizi örneği. Kastamonu Eğitim Dergisi, 26(2), 599-611. https://doi.org/10.24106/kefdergi.404885

Vygotsky, L. S. (1980). Mind in society: The development of higher psychological processes. Cambridge, MA: Harvard University Press. https://doi.org/10.2307/j.ctvjf9vz4

Yağar, F., \& Dökme, S. (2018). Niteliksel araştirmalarin planlanmasi: Araştirma sorulari, örneklem seçimi, geçerlik ve güvenirlik. Gazi Sağlık Bilimleri Dergisi, 3(3), 1-9.

Yıldırım, A., \& Şimşek H. (2013). Sosyal bilimlerde nitel araştırma yöntemleri. Ankara: Seçkin Yayıncılık.

\section{Copyright Disclaimer}

Copyright for this article is retained by the author(s), with first publication rights granted to the journal.

This is an open-access article distributed under the terms and conditions of the Creative Commons Attribution license (http://creativecommons.org/licenses/by/3.0/). 